\title{
The impact of exchange rate volatility on emerging market exports
}

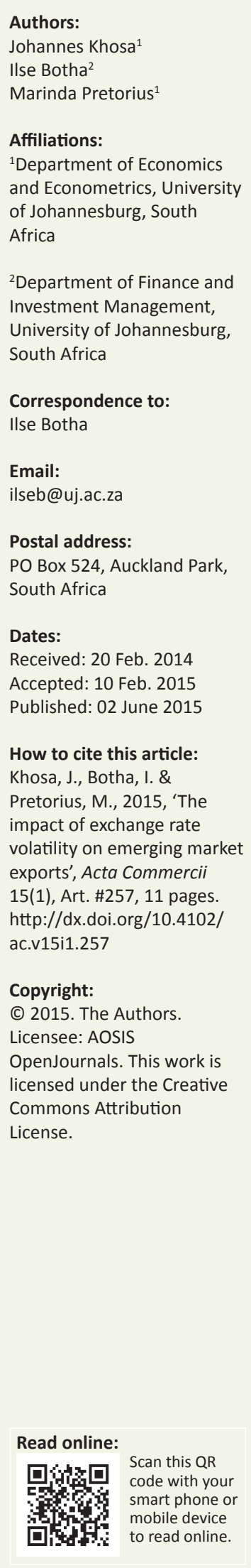

Orientation: High exchange rate volatility has implications for business and policy decisions and exchange rate movements are important in debates around trade and trade policies.

Research purpose: The purpose of the research was to determine the impact of exchange rate volatility on exports in emerging markets.

Motivation for the study: A lack of clarity in literature regarding this relationship increases the risk of improper planning by export organisations as well as implementing suboptimal economic policies.

Research design, approach and method: This research analysed the effect of exchange rate volatility on emerging market exports using a sample of nine emerging countries from 1995 to 2010. Panel data analysis was conducted. Volatility was measured by Generalised Autoregressive Conditional Heteroscedasticity and conventional standard deviation in order to determine if the instrument of volatility used influenced the nature of the relationship between exchange rate volatility and exports. The Pedroni residual cointegration method was used to test for panel cointegration in order to determine if there was a long-run relationship.

Main findings: The results showed that exchange rate volatility had a significant negative effect on the performance of exports, regardless of the measure of volatility used. It was also evident that a long-run relationship did exist.

Practical/managerial implications: The study concluded that the policy mix that will reduce exchange rate volatility (such as managed exchange rate regimes) and relatively competitive exchange rates were essential for emerging markets in order to sustain their exports performance.

Contribution/value-add: This research provided policy makers of emerging market economies with new evidence pertaining to the relationship between exchange rate volatility and the performance of exports. This research contributed to the existing knowledge on the topic and provides a base for future research on related topics.

\section{Introduction}

Countries have monetary policies that maintain exchange rates and they adopt either fixed or flexible exchange rate regimes. In recent times, most countries have a flexible exchange rate system. As this type of exchange rate system gained popularity, countries liberalised their economies, the effect of globalisation intensified and economic cooperation and trade between countries increased, exchange rate volatility also increased. As a result, the role of exchange rate uncertainty on trade became one of the critical issues for economic policy makers. Debates around this issue emanate because there is no consensus on whether exchange rate volatility affects foreign trade activity. By only looking at raw data without in-depth analysis, it is difficult to determine the nature of the relationship and a lack of clarity on this issue increases the risk of improper planning by exporting organisations as well as implementing suboptimal economic policies.

The debate on exchange rate volatility and exports is gaining attention in emerging market countries because the markets are characterised by high levels of exchange rate volatility compared with developed countries (Darrat \& Hakim 2000). Added to this, there are fewer studies that focus on this issue for emerging markets. A lack of consistent empirical evidence on emerging markets on the topic of exchange rate volatility and exports means that the question of the relationship between the two variables remains unanswered. Whilst the actual data show that exports have been showing an upward trend over the past two decades or so, these do not clearly indicate if the volatility of exchange rates has hampered export growth. A compelling conclusion on the nature of the relationship between the variables cannot be drawn through a simple cursory overview of the data. Econometric analysis is necessary in order to make empirical assessment. 
The key research question for this research is: 'Does exchange rate volatility affect emerging market exports?' The primary objective of this research is to answer the above question and to determine whether the effect is negative or positive. The secondary objective is to determine the extent to which the relationship between exchange rate volatility and exports is influenced by the measure of volatility.

\section{Literature review}

\section{Exchange rate volatility and exports}

The analysis pertaining to the effect of exchange rate volatility on exports relates to that of the behaviour of producers under uncertainty. As defined by Marston (1987), exchange rate volatility entails a random movement of the exchange rate. Such unpredictable movement presents uncertainty in the operational environment and increases profit uncertainty. However, the traders and investors respond differently to uncertainty, which creates a division of views regarding this issue. Three views are held on how exchange rate volatility affects exports. Some theories argue that the volatility has a negative effect on trade, others believe that it has a positive influence, whilst some believe that there is no relationship between the variables.

The theories that support the negative effect of exchange rate volatility on exports perceive that since exchange rate volatility presents uncertainty in the business environment, rational traders tend to avoid or reduce their exposure to uncertainty and any other form of risk by adjusting trade activities. Clark (1973) is one of the researchers whoestablished a negative relationship between exchange rate volatility and exports. He argued that in the absence of hedging facilities and producers are risk averse, an increase in exchange rate volatility would cause them to reduce their risk exposure in order to prevent its impact on the profitability. They respond by reducing output and therefore export volumes. This view was also supported by Broda and Romalis (2003), who found that if the exporter's primary objective is to maximise profit, they are more likely to reduce their exposure to any kind of risk, including exchange rate volatility. Vergil (2002) further argued that volatility causes exports to underperform because, in addition to creating uncertainty and effecting planning, it discourages local suppliers from expanding into foreign markets on fear of being exposed to profit variability which may result from unstable exchange rates. In a free market, exporters have a choice to exit the market when they perceive the environment to be too risky and to re-enter when stability returns. Franke (1991) and Sercu and Vanhulle (1992) demonstrated that if the costs of entering or exiting the market are lower, exporters would easily cut exports and exit the market when volatility increases.

Earlier studies found a negative relationship between exchange rates and exports; these include, inter alia, Thursby and Thursby (1987), De Grauwe (1988), Brada and Méndez (1988), Koray and Lastrapes (1989), Chowdhury (1993) and Obstfeld and Rogoff (1995). These findings persisted in later research, such as Aristotelous (2001), Anderton and Skudelny (2001), Dogănlar (2002), Arize, Malindretos and Kasibhatla (2003), Baak, Al-Mahmood and Vixathep (2007), Cho, Sheldon and McCorriston (2002), Clark et al. (2004), Tenreyro (2007), De Vita and Abbott (2004), Bah and Amusa (2003), Takaendesa, Tsheole and Aziakpono (2005), Hall et al. (2010), Héricourt and Poncet (2013), Chit, Rizov and Willenbockel (2010), Verheyen (2012) and Grier and Smallwood (2013). Most of these studies looked at developed countries and they found that there is a negative relationship between exchange rate instability and the performance of exports within this group.

In contrast to the above-discussed view, some theories state that exchange rate volatility could in fact underpin exports. This occurs because some exporters subscribe to the low-risklow-return practice, tending to export more when exchange rate volatility is high (Côté 1994). The rationale behind this practice is that when exporters expect marginal revenue to decline as the exchange rate volatility increases, they will be induced to increase export volumes in order to make up for the likelihoods of reduction in marginal revenue. According to De Grauwe (1988), Kroner and Lastrapes (1993) and Égert and Morales-Zumaquero (2008), some traders may increase trade when they expect the environment to deteriorate further in the future due to the persistent exchange rate volatility. This will induce current trade as traders rush to conclude transactions and make up for the expected decline in activity and profit in the event when exchange rate volatility persist for an extend period. The argument was also supported by Bailey, Tavlas and Ulan (1987:230), who debated that '.. if exporters are sufficiently risk-averse, an increase in exchange rate volatility raises expectations for a reduction in marginal utility of export revenue'. This concern will encourage exporters to increase their current export volumes, in an attempt to maximise profits and to make up for the likelihoods of the reduction in future profits in the event where the volatility persists.

In contrast to most conventional views, some theories and studies are unable to determine any form of relationship between exchange rate volatility and exports. The unlikely effect of exchange rate volatility on exports is prevalent in countries with good hedging facilities, where future trade transactions are concluded at a certain exchange rate level. Any future movement of the exchange rate should thus not affect the already pegged price and volume of goods and services to be delivered. Hooper and Kohlhagen (1978) investigated how exchange rate instability affected both bilateral and multilateral trade amongst developing countries during 1965 to 1975 and could not establish a significant connection between the variables. Clark et al. (2004) established that exchange rate volatility has no significant influence on trade. Likewise, Solakoglu, Solakoglu and Demirağ (2008) found that for some firms in Turkey, there was no negative or positive influence of the exchange rate instability on exports. The study by Hall et al. (2010) found a significant negative relationship for developed countries but no significant relationship for emerging markets. The reason of no effect in this case results 
from the openness of the capital markets of these countries. Other researchers who were unable to empirically confirm the influence of exchange rate volatility on trade are Gotur (1985) and Klaassen (2004), as well as Asseery and Peel (1991). A summary of the available studies pertaining to the effect of exchange rate volatility on exports and tools of analysis used are presented in Appendix 1 for further reference.

Literature suggested that there is no clear indication regarding the direction of the relationship between exchange rate volatility and exports performance, however the main findings in literature do suggest a negative relationship. Exchange rate volatility could carry both costs and benefits, with exporters responding differently to risk posed by the volatility.

\section{Panel data models}

The panel data set is one where there are repeated observations on the same units (Gujarati 2003). The benefits of panel data compared with other models include its ability to control the impact of omitted variables (MaCurdy 1981), the flexibility to allow for accurate adjustments of the parameters (Hsiao, Mountain \& Ho Illman 1995), as well as the reduction of measurement errors (Hsiao 2006) and the flexibility to focus on individual countries' specific effects (Gujarati 2003). Three panel data models, namely the pooled, the fixed effect and the random effect models, are explored in this research and then statistical tests are used to choose the most appropriate model, which will be the core model for the study.

\section{Pooled model}

The pooled model estimates a linear relationship between the dependent variable and the explanatory variables. It assumes a normally distributed residual, constant variance and the value of the error term to be zero (Wooldridge 2002). It also restricts the coefficients of the explanatory variables to be common across $i$ th units $(i)$ and time periods $(t)$. However, the pool models do not allow control for unobserved individual heterogeneity or specific effects, which could result in unbiased estimates (Hsiao 2006). To overcome this problem, least squares dummy variable (LSDV), the fixed effects and the random effects models could be fitted.

\section{Least Squares Dummy Variable}

The LSDV model estimates the fixed effects by allowing for the intercepts of the countries to vary and it assumes normal distribution of the residuals. Each dummy is absorbing the effects of each particular country. However, the LSDV model also has some weaknesses, including the fact that it consumes a lot of degrees of freedom if too many dummies are employed (Greene 2000). Moreover, if there are several crosssections in the model, multicollinearity may be experienced, which may increase the standard errors of the model and affect the accuracy of the results. Lastly, although the LSDV model assumes homogenous and normal distribution of the residuals in the model, country-specific heteroscedasticity and autocorrelation may still exist and distort the estimation (Greene 2000). The problems of heteroscedasticity and autocorrelation can be solved in the fixed effect generalised least squares (GLS) models, which allow the use of weighted least squares to correct the error terms.

\section{The fixed effect model}

Unlike the LSDV models, the fixed effect model assumes that the slope coefficients are constant, therefore they do not vary across the individual countries or over time (Hedeker \& Gibbons 1994). However, it allows the intercepts to vary according to cross-section units. Unlike the pooled model, which assumes constant coefficients, the fixed effect model therefore acknowledges that the intercepts of the countries could differ due to individual country's specific effects, such as policies, political situations and compositions of exports (Hedeker \& Gibbons 1994). The GLS model is used to account for heteroscedasticity and autocorrelation in the error term (Robinson 1987).

\section{Random effect model}

The random effect models assume that individual countryspecific effects are random variables which are uncorrelated with the explanatory variables (Longford 1993). They therefore randomly distribute individual specific constant terms across the cross-section units (Cakir 2008). One of the advantages of these models is that the estimation of $N$ cross-sectional intercepts is not necessary, which makes the models to be more economical in terms of the use of degrees of freedom. A detailed discussion on panel data methods can be found in Wooldridge (2002).

\section{Research method and design}

This study uses panel data tools for the benefits outlined above. A sample of nine emerging countries, namely Argentina, Brazil, India, Indonesia, Mexico, Malaysia, Poland, South Africa and Thailand, was used. The countries were selected from various regions within the emerging market group as per the International Monetary Fund country grouping. The countries produce different goods and services, large portions of which are exported either directly or indirectly to developed countries. The countries have flexible exchange rate regimes and have volatile exchange rates. They are the largest economies in the group in terms of nominal gross domestic profit (GDP). Panel data methods were most suited for this analysis to account for the said heterogeneity. Data availability was also taken into consideration. The data were collected from Datastream on a monthly- and seasonally-adjusted basis over the period 1995 to 2010 . Therefore, the pooled data will have 1728 observations (i.e., 192 months multiplied by nine countries). The G7 industrial production was collected in constant US dollar terms, whilst exports data was collected in local currency terms at constant 1995 prices. Exchange rate volatilities were calculated from real effective exchange rates from the country's central banks. Real effective exchange rates were also used as an indicator of exchange rate levels. All the data, except for exchange rate volatility, were rebased, with January 1995 as the base year. 
The key variables on this study are exports, exchange rate volatility, exchange rate levels, industrial production and terms of trade. A negative relationship is expected to prevail between a stronger exchange rate and the performance of exports, because stronger exchange rates make the exports to be expensive relative to those of other competitors. The opposite effect is expected for a weaker exchange rate. Since G7 countries are major global consumers, an increase in their industrial production indicates an increase in economic activity in those countries, which should push demand for imports from emerging markets. Therefore a positive relationship between G7 industrial production and emerging market exports should be expected (Baak et al. 2007; Kandilov 2008). Terms of trade measure countries' competitiveness, hence an increase in terms of trade is expected to have a positive effect on exports (Dogănlar 2002). The relationship between exchange rate volatility is the main subject matter for this study. As discussed in the literature review section, the effect of exchange rate volatility on exports could be positive, negative or none.

The accurate measure of exchange rate volatility is a controversial issue as there are various methods that can used, each with its own advantages and disadvantages. This research uses both the standard deviation and the Generalised Autoregressive Conditional Heteroscedasticity (GARCH). The use of both measures will help to determine the extent (if any) of difference in the results produced of the estimations with different measures of volatility. The standard deviation formula is estimated as follows:

$v=\left[(1 / m) \sum_{\mathrm{i}=1}^{\mathrm{m}}\left(E R_{\mathrm{t}-1}-E R_{\mathrm{t}-2}\right)^{2}\right]^{1 / 2}$

where $E R$ is the exchange rate of the local currency against the US dollar and 1 is the mean or order of the moving average.

TABLE 1: Panel unit root test: Exports.

\begin{tabular}{lcccc}
\hline Method & \multicolumn{3}{c}{ Level } \\
\cline { 2 - 5 } & Statistic & Probability & Cross-section & Observation \\
\hline Levin, Lin \& Chu $t$ & -0.310 & 0.378 & 9 & 1683 \\
$\begin{array}{l}\text { Im, Pesaran \& Shin } \\
\text { W-statistic }\end{array}$ & 1.491 & 0.932 & 9 & - \\
1st difference & & & & \\
Levin, Lin \& Chu $t$ & -6.979 & $0.000^{*}$ & 9 & 1674 \\
$\begin{array}{l}\text { Im, Pesaran \& Shin } \\
\text { W-statistic }\end{array}$ & -14.959 & $0.000^{*}$ & 9 & 1674 \\
\hline
\end{tabular}

Source: Eviews results (Eviews 6 Student Version, Quantitative Micro Software LLC 2007) $*$, indicates the rejection of the hypothesis of non-stationarity at $1 \%$ level of significance.

TABLE 2: Panel unit root test: Exchange rate volatility - with Generalised Autoregressive Conditional Heteroscedasticity.

\begin{tabular}{lcccc}
\hline Method & \multicolumn{3}{c}{ Level } \\
\cline { 2 - 5 } & Statistic & Probability & Cross-section & Observation \\
\hline Levin, Lin \& Chu $t$ & -3.716 & $0.000 *$ & 9 & 1683 \\
Im, Pesaran \& Shin & -11.190 & $0.000 *$ & 9 & 1683 \\
W-statistic & & & & \\
1st difference & & & & \\
Levin, Lin \& Chu $t$ & -9.29 & $0.044^{*}$ & 9 & 1674 \\
Im, Pesaran \& Shin & -26.1 & $0.000 *$ & 9 & 1674 \\
W-statistic & & & & \\
\hline
\end{tabular}

Source: Eviews results (Eviews 6 Student Version, Quantitative Micro Software LLC 2007) GAurce: Eviews results (Eviews 6 Student Version, Quantitative Micro

$*$, indicates the rejection of the hypothesis of non-stationarity at $1 \%$ level of significance.

The GARCH model models volatility through the change in the log of the exchange rate. It also accounts for volatility clustering in the time series (Brooks 2002). The GARCH model is estimated as follows:

$$
\begin{aligned}
\log \left(\mathrm{ER}_{\mathrm{t}}\right)= & \alpha+\beta 1\left(\mathrm{ER}_{\mathrm{t}-1}\right)+\beta 2 \log \left(\mathrm{ER}_{\mathrm{t}-2}\right)+\varepsilon_{\mathrm{t}}, \\
& \text { where } \quad \varepsilon_{\mathrm{t}} \sim \mathrm{N}\left(0, V_{\mathrm{t}}^{2}\right)
\end{aligned}
$$

$V_{\mathrm{t}}^{2}=\mu+\mu 1 \mathrm{e}_{\mathrm{t}-1}^{2}+\mu 2 V_{\mathrm{t}-1}^{2}$

Equation 3 is the conditional variance, which is a function of the mean $(\mu)$, the news about exchange rate volatility from the previous period, represented by the lag of the squared residual from the mean $\mathrm{e}_{\mathrm{t}-1}^{2}$ (which is the $\mathrm{ARCH}$ term) and the last period's forecast error variance $V_{\mathrm{t}-1}^{2}$ (which is the GARCH term) (Onofowora \& Owoye 2008). The application $\operatorname{GARCH}(p, q)$, with $\operatorname{GARCH}(1): \mathrm{ARCH}(1)$, from now on to be represented as $\operatorname{GARCH}(1,1)$, is used. The sign of the relationship between exchange rate volatility and exports depends on the extent to which the exporters are risk averse (International Monetary Fund 1984) and (Clark et al. 2004).

\section{Results}

\section{Unit root test and cointegration}

Generally, panel data series, by their nature, are likely to show some degree of heterogeneity. In studies such as this one, where the sample has countries with unique characteristics, the individual variables may not have the same properties. The series may thus not be stationary and models with nonstationary data could lead to a spurious regression, with invalid coefficients and goodness of fit (Hoover 2003). In this research, Im, Pesare and Shin (IPS) (2003) and Levin, Lin and Chu (LLC) (2002) methods were used to test for data stationarity. The results of the tests are presented in Tables 1 to 6 .

\begin{tabular}{|c|c|c|c|c|}
\hline \multirow[t]{2}{*}{ Method } & \multicolumn{4}{|c|}{ Level } \\
\hline & Statistic & Probability & Cross-section & Observation \\
\hline Levin, Lin \& Chu $t$ & -4.45 & $0.000 *$ & 9 & 1683 \\
\hline $\begin{array}{l}\text { Im, Pesaran \& Shin } \\
\text { W-statistic }\end{array}$ & -11.19 & $0.000 *$ & 9 & 1683 \\
\hline \multicolumn{5}{|l|}{ 1st difference } \\
\hline Levin, Lin \& Chu $t$ & 5.81 & $0.002 *$ & 9 & 1674 \\
\hline $\begin{array}{l}\text { Im, Pesaran \& Shin } \\
\text { W-statistic }\end{array}$ & -28.61 & $0.000 *$ & 9 & 1674 \\
\hline
\end{tabular}

TABLE 3: Panel unit root test: Exchange rate level - with standard deviation.

$*$ indicates the rejection of the hypothesis of non-stationarity at $1 \%$ level of significance.

TABLE 4: Panel unit root test: Exchange rate level.

\begin{tabular}{lcccc}
\hline Method & \multicolumn{4}{c}{ Level } \\
\cline { 2 - 5 } & Statistic & Probability & Cross-section & Observation \\
\hline Levin, Lin \& Chu $t$ & 0.864 & 0.806 & 9 & 1683 \\
$\begin{array}{l}\text { Im, Pesaran \& Shin } \\
\text { W-statistic }\end{array}$ & -0.660 & 0.255 & 9 & 1683 \\
$\begin{array}{l}\text { 1st difference } \\
\text { Levin, Lin \& Chu } t\end{array}$ & -8.265 & $0.000^{*}$ & 9 & 1674 \\
$\begin{array}{l}\text { Im, Pesaran \& Shin } \\
\text { W-statistic }\end{array}$ & -14.746 & $0.000 *$ & 9 & 1674 \\
\hline $\begin{array}{l}\text { Source: Eviews results (Eviews 6 Student Version, Quantitative Micro Software LLC 2007) } \\
\text { *, indicates the rejection of the hypothesis of non-stationarity at 1\% level of significance. }\end{array}$
\end{tabular}


TABLE 5: Panel unit root test: Terms of trade.

\begin{tabular}{lcccc}
\hline Method & \multicolumn{3}{c}{ Level } \\
\cline { 2 - 5 } & Statistic & Probability & Cross-section & Observation \\
\hline Levin, Lin \& Chu $t$ & -0.896 & 0.185 & 9 & 1683 \\
$\begin{array}{l}\text { Im, Pesaran \& Shin } \\
\text { W-statistic }\end{array}$ & -1.362 & 0.086 & 9 & 1683 \\
1st difference & & & & \\
Levin, Lin \& Chu $t$ & -10.735 & $0.000 *$ & 9 & 1674 \\
$\begin{array}{l}\text { Im, Pesaran \& Shin } \\
\text { W-statistic }\end{array}$ & -15.651 & $0.000^{*}$ & 9 & 1674 \\
\hline
\end{tabular}

Source: Eviews results (Eviews 6 Student Version, Quantitative Micro Software LLC 2007)

$*$, indicates the rejection of the hypothesis of non-stationarity at $1 \%$ level of significance.
TABLE 6: Panel unit root test: G7 Industrial production.

\begin{tabular}{lcccc}
\hline Method & \multicolumn{3}{c}{ Level } \\
\cline { 2 - 5 } & Statistic & Probability & Cross-section & Observation \\
\hline Levin, Lin \& Chu $t$ & 3.668 & 0.999 & 9 & 1683 \\
Im, Pesaran \& Shin & 6.242 & 1.000 & 9 & 1683 \\
$\begin{array}{l}\text { W-statistic } \\
\text { 1st difference }\end{array}$ & & & & \\
$\begin{array}{l}\text { Levin, Lin \& Chu } t \\
\text { Im, Pesaran \& Shin }\end{array}$ & -3.745 & $0.000^{*}$ & 9 & 1674 \\
W-statistic & -12.696 & $0.000^{*}$ & 9 & 1674 \\
\hline
\end{tabular}

Source: Eviews results (Eviews 6 Student Version, Quantitative Micro Software LLC 2007) G7, a group of seven largest industrialised nations in the world, namely, Italy, France, USA Germany, Japan, the UK and Canada.

$*$ indicates the rejection of the hypothesis of non-stationarity at $1 \%$ level of significance.

TABLE 7a: Pedroni residual cointegration test.

\begin{tabular}{|c|c|c|c|c|c|c|c|c|}
\hline \multirow[t]{2}{*}{ Panels } & \multicolumn{4}{|c|}{$\begin{array}{l}\text { Series with GARCH Common autoregressive } \\
\text { coefficients (within-dimension) }\end{array}$} & \multicolumn{4}{|c|}{$\begin{array}{l}\text { Series with Standard deviation Common } \\
\text { autoregressive coefficients (within-dimension) }\end{array}$} \\
\hline & Statistic & Probability & Weighted & Probability & Statistic & Probability & Weighted & Probability \\
\hline Panel v & -9.162 & $0.000^{*}$ & -8.790 & $0.000 * *$ & -9.344 & $0.000 *$ & -11.548 & $0.000 *$ \\
\hline Panel PP & -14.667 & $0.000^{*}$ & -21.125 & $0.000 *$ & -14.622 & $0.000 *$ & -20.882 & $0.000 *$ \\
\hline Panel ADF & -10.612 & $0.000 *$ & -14.179 & $0.000 *$ & -10.688 & $0.000 *$ & -14.121 & $0.000 * *$ \\
\hline
\end{tabular}

Source: Eviews results (Eviews 6 Student Version, Quantitative Micro Software LLC 2007)

GARCH, Generalised Autoregressive Conditional Heteroscedasticity; ADF, Augmented Dickey Fuller; PP, Phillips Perron.

$*, * *$, indicate the rejection of the hypothesis of non-stationarity at $1 \%$ and $5 \%$ level of significance, respectively.

TABLE 7b: Pedroni residual cointegration test.

\begin{tabular}{lccc}
\hline Groups & & Individual autoregressive coefficients (between-dimension) \\
\cline { 2 - 4 } & Statistic & Probability & Statistic \\
\hline Group rho & -26.867 & $0.000^{*}$ & -26.913 \\
Group PP & -24.365 & $0.000 *$ & -24.266 \\
Group ADF & -16.847 & $0.000 *$ & -16.951 \\
\hline
\end{tabular}

Source: Eviews results (Eviews 6 Student Version, Quantitative Micro Software LLC 2007)

GARCH, Generalised Autoregressive Conditional Heteroscedasticity; ADF, Augmented Dickey Fuller; PP, Phillips Perron.

*,**, indicate the rejection of the hypothesis of non-stationarity at $1 \%$ and $5 \%$ level of significance, respectively.

The results show that exchange rate volatility (measured by both GARCH and standard deviation) was stationary at its level, integrated at $\mathrm{I}(0)$ whilst exports, exchange rate level, terms of trade and G7 industrial production were not stationary at their levels, but were integrated to the first order, I(1). Whilst regression with non-stationary variables will yield spurious results, when the variables are cointegrated, there is no need to worry about spurious regression. Cointegration occurs when the errors of nonstationary series cancel each other out, resulting in a stationary error term. This implies that the variables may not be moving together in the short-run but have a true relationship in the long run (Perman \& Stern 2003). Pedroni residual cointegration method was used to test for panel cointegration. The method was adopted for its advantage over other methods such as the Engle Granger residual based approach. The main advantage of Pedroni, particularly relevant for the purpose of this study, is that it allows the mixture of different orders (Im, Pesaran \& Shin 2003), whilst the Engle Granger approach focuses on the case where the variables are integrated in first order I(1) only (Pesaran, Shin \& Smith 2001). As indicated in the unit root test result, exchange rate volatility was found to be stationary at their level, that is, $\mathrm{I}(0)$, whilst the other variables were integrated to the first order, I(1). All the variables were included in the Pedroni cointegration test and they were tested at their levels. The results of the cointegration test are presented in Table $7 \mathrm{a}$ and Table $7 \mathrm{~b}$.
The null hypothesis proposed by Pedroni (1999) for the test is that there is no cointegration. The results show significant $t$-statistics and $p$-values, and the null hypothesis is rejected at the $99 \%$ level of confidence. This confirms that cointegration exists amongst the variables and there is, therefore, no need to be concerned about spurious regression. Since cointegration exists between these variables, the level data can be used in the specification of the model in the next section.

\section{Specification of the model}

The model for this study is based on a standard exports equation, with the performance explained by exchange rate volatility, the level of the exchange rate, demand conditions in major countries and terms of trade. The data for all the variables, except for exchange rate volatility, was logged. The generic export equation is therefore estimated as:

$$
\begin{aligned}
\log (\text { Yit })= & \alpha+\beta \times 1 \text { it }+\log (\beta \times 2 i t)+\log (\beta \times 3 \text { it }) \\
& +\log (\beta \times 4 \text { it })+u_{i t}
\end{aligned}
$$

and, therefore:

$\log ($ exports $)=\alpha+$ exchange rate volatility $+\log ($ exchange rate $)$

$$
+\log (\mathrm{G} 7 \text { industrial production })
$$$$
+\log (\text { terms of trade })+u_{i t}
$$ 


\section{The selection of the appropriate model}

Statistical tests were used to choose the appropriate model. The LSDV model estimates the fixed effects by allowing for the intercepts of the countries to vary and it assumes normal distribution of the residuals. Each dummy absorbs the effects of each particular country. The results of the LSDV estimation, with South Africa as a benchmark country, are presented in Table 8 .

As discussed earlier, despite the advantage of making it possible to compare individual country-specific effects, the LSDV model has several limitations. As a result, it was used in this research. The fixed and random effect models were employed. Before the models are estimated appropriately, it is essential to check if the countries are similar (in case of the fixed effect) and if there are random effects (in case of the random effect) in the models. The redundant fixed effect test was used to test if there are similarities in the countries. The results are presented in Table 9.

The hypothesis is that the countries are different from each other. The outcome of the test shows that the null hypothesis is rejected at $1 \%$ level of confidence. Therefore, the countries are different and that fixed panel models could be carried out appropriately. The redundant fixed effect test therefore shows that the coefficients in the fixed effect models are significantly different and suggested that the fixed effect model could be appropriate. However, it is also crucial to test which method between the fixed and random effect model is most appropriate to account for heterogeneity. The Hausman test was conducted in order to check for the presence of random effect in the models and the results are presented in Table 10.

The Hausman test checks the presence of the random effects in the random effect models. It checks whether the unique error terms are correlated with the explanatory variables (Greene 2000). The hypothesis as per Hausman (1978) is, therefore, that the error terms are not correlated with the regressors. The results, presented in Table 11, show that the $p$-values in both models (i.e., with GARCH and standard deviation) are greater than 0.05 , which implied that the null hypotheses cannot be rejected. This confirms that the errors are not correlated with the explanatory variables and therefore that the random effect model, which allows for time-invarying effects in the error term, would produce more efficient estimates than the pooled model. Based on the results of these tests, the random effect model was adopted as the core model for this research. Moreover, the random

TABLE 8: LSDV estimation (dependent variable: exports).

\begin{tabular}{|c|c|c|c|c|}
\hline \multirow[t]{2}{*}{ Variable } & \multicolumn{2}{|c|}{ A-GARCH } & \multicolumn{2}{|c|}{ B - Standard deviation } \\
\hline & Coefficient & $P$-values & Coefficient & $P$-values \\
\hline ExRateVOL & -0.21 & $0.013 * *$ & -0.30 & $0.033^{* *}$ \\
\hline ExRate & -0.35 & $0.001 *$ & -0.35 & $0.001 *$ \\
\hline G7 & 5.51 & $0.000 *$ & 5.54 & $0.000 *$ \\
\hline Tot & 0.75 & $0.021 * *$ & 0.77 & $0.020 * *$ \\
\hline Argentina & 42.42 & $0.000 *$ & 42.34 & $0.000 *$ \\
\hline Brazil & 106.64 & $0.000 *$ & 107.22 & $0.000 *$ \\
\hline India & 63.54 & $0.000 *$ & 64.54 & $0.000 *$ \\
\hline Indonesia & 50.16 & $0.003 *$ & 49.04 & $0.002 *$ \\
\hline Malaysia & 55.21 & $0.000 *$ & 56.09 & $0.000 *$ \\
\hline Mexico & 149.07 & $0.000 *$ & 149.03 & $0.000 *$ \\
\hline Poland & 165.76 & $0.000 *$ & 166.74 & $0.000 *$ \\
\hline Thailand & 22.92 & $0.050 * *$ & 22.95 & $0.053^{* *}$ \\
\hline$R$-squared & 0.57 & - & 0.56 & - \\
\hline Adjusted R-squared & 0.56 & - & 0.56 & - \\
\hline
\end{tabular}

TABLE 9: Redundant fixed effects tests.

\begin{tabular}{|c|c|c|c|c|c|c|}
\hline \multirow[t]{2}{*}{ Method - Effects test } & \multicolumn{3}{|c|}{ GARCH } & \multicolumn{3}{|c|}{ Standard deviation } \\
\hline & Statistic & d.f. & $P$-value & Statistic & d.f. & $P$-value \\
\hline Cross-section F & 103.8 & $(8,158)$ & $0.000 *$ & 116.184 & $(8,158)$ & $0.000 *$ \\
\hline Cross-section Chi-square & 673.0 & 8 & $0.000 *$ & 736.999 & 8 & $0.000 *$ \\
\hline
\end{tabular}

Source: Eviews results (Eviews 6 Student Version, Quantitative Micro Software LLC 2007)

d.f. - Degrees of freedom; $P$-value, Probability value; GARCH, Generalised Autoregressive Conditional Heteroscedasticity.

$*$, indicates the rejection of the hypothesis of non-stationarity at $1 \%$ level of significance.

TABLE 10: Random effects - Hausman test.

\begin{tabular}{lcccccc}
\hline $\begin{array}{l}\text { Method - Test } \\
\text { Summary }\end{array}$ & \multicolumn{3}{c}{ GARCH (1:1) } & & \multicolumn{2}{c}{ Standard deviation } \\
\cline { 2 - 3 } & Chi-square statistic & Chi-square d.f. & Probability & & Chi-square statistic & Chi-square d.f. \\
\hline Cross-section random & 6.634 & 4 & 0.1566 & & 6.203 & \\
\hline
\end{tabular}

Source: Eviews results (Eviews 6 Student Version, Quantitative Micro Software LLC 2007)

d.f., Degrees of freedom; $P$-value, Probability value; GARCH, Generalised Autoregressive Conditional Heteroscedasticity. 
TABLE 11: Dependent variable: Exports.

\begin{tabular}{|c|c|c|c|c|c|c|}
\hline \multirow[t]{2}{*}{ Method } & \multicolumn{2}{|r|}{ OLS } & \multicolumn{2}{|c|}{ Fixed effect model } & \multicolumn{2}{|c|}{ Random effect model } \\
\hline & A-GARCH & B-Standard deviation & C-GARCH & D-Standard deviation & E-GARCH & F-Standard deviation \\
\hline \multirow[t]{3}{*}{ Exchange rate volatility } & $-0.860 * *$ & $-3.644 *$ & $-2.577 * *$ & $-3.142 *$ & $-2.566 * *$ & $-3.153^{*}$ \\
\hline & -2.025 & -3.366 & -2.467 & -3.560 & -2.455 & -3.720 \\
\hline & 0.042 & 0.063 & 1.045 & 0.029 & 0.045 & 0.028 \\
\hline \multirow[t]{2}{*}{ Real exchange rate } & $-0.050 * *$ & $-0.115 * *$ & $-0.307^{*}$ & $-0.278 *$ & $-0.269 *$ & $-0.300 *$ \\
\hline & -0.642 & -0.555 & -5.896 & -8.076 & -6.431 & -5.965 \\
\hline \multirow[t]{3}{*}{ G7 industrial production } & $3.209 *$ & $5.384^{*}$ & $5.182^{*}$ & $4.784 *$ & $1.618^{*}$ & $1.621 *$ \\
\hline & -9.871 & -12.043 & -12.104 & -9.724 & -2.871 & -2.839 \\
\hline & 0.097 & 0.447 & 0.428 & 0.492 & 0.012 & 0.018 \\
\hline \multirow[t]{3}{*}{ Terms of trade } & $1.785 * *$ & $1.979 * *$ & $0.746 * *$ & $0.778 * *$ & $0.731^{* *}$ & $0.758 * *$ \\
\hline & -1.979 & -1.954 & -1.729 & -1.952 & -1.022 & -1.124 \\
\hline & 0.039 & 0.044 & 0.1302 & 0.157 & 0.121 & 0.148 \\
\hline Adjusted $R$-square & 0.242 & 0.221 & 0.98 & 0.98 & 0.839 & 0.839 \\
\hline
\end{tabular}

Source: Eviews results (Eviews 6 Student Version, Quantitative Micro Software LLC 2007)

GARCH, Generalised Autoregressive Conditional Heteroscedasticity; OLS, Ordinary Least Square; G7, a group of seven largest industrialised nations in the world, namely, Italy, France, USA, Germany, Japan, the UK and Canada; TOT, Terms of Trade.

$*, * *$, indicate the rejection of the hypothesis of non-stationarity at $1 \%$ and $5 \%$ level of significance, respectively.

effect model has further advantages over the fixed effect model because it is economical in degrees of freedom as there is no need to estimate the number of cross-section intercepts. According to Judge et al. (1985) when the number of time series data $(\mathrm{T})$ is small and the number of cross-sectional unit $(\mathrm{N})$ is large, a random effect model could be appropriate. In this study, the time series (192 months) is large and the crosssection (nine) is not small either.

\section{Empirical analysis - panel data with random effect models}

According to literature, no consensus was established regarding whether exchange rate volatility affects exports either negatively or positively. This section will present the empirical findings of this study. Tree panel data models were estimated and the results are presented in Table 11. In the table, column A and B show the results of the estimations by the ordinary least squares, fixed effects (columns C and D) and random effect models (columns $\mathrm{E}$ and F). As discussed above, statistical tests were used to choose the random effect model as the appropriate model for this research.

White's cross-section standard errors and covariance methods were used to correct for heteroscedasticity and autocorrelation in order to obtain correct standard errors. The coefficients in the core models (i.e., the random effect models) make economic sense, are in line with preliminary expectations and support the arguments by most of other theories and similar empirical studies reviewed earlier. The results confirm that the performance of exports is driven by various factors in the economy, including exchange rate volatility, the level of the exchange rate, economic activities and terms of trade.

\section{Discussion}

\section{Outline of the results}

The aim of this research was to analyse the determinants of exports, with a specific focus on the effect of exchange rate volatility on the performance of exports. Panel data models were used to determine the nature of the relationship between the two variables in a sample of nine emerging countries. Two measures of exchange rate volatility, namely standard deviation and GARCH, were used.

Both models (i.e., the one with exchange rate volatility measured by GARCH [column E] and the one with exchange rate volatility measured by standard deviation [column F] in Table 11) showed that exchange rate volatility has a negative effect on exports. The effect is significant at $1 \%$ and $5 \%$ levels. A $1 \%$ increase in exchange rate volatility, ceteris paribus, reduces exports by about $2.57 \%$ (according to the model with GARCH) and 3.15\% (according to the model with standard deviation). The coefficients of the models showed that exchange rate volatility has a statistically significant negative effect on exports, regardless of the measure of volatility used. The magnitude of the difference between the effect by GARCH (with a coefficient of 2.566) and standard deviation (with a coefficient of 3.153) is relatively marginal. These empirical results are also consistent with those of other studies on similar topics, such as Chit (2008), Clark et al. (2004), Aghion et al. (2006), Héricourt and Poncet (2013), Chit et al. (2010) and Verheyen (2012), which found that the impact of exchange rate volatility on exports is negative and small and does not depend on the measure used as a proxy of exchange rate volatility. However, the coefficients of the model with the standard deviation measure are slightly larger than those with GARCH. This reflects the fact that the GARCH series accounts for data clustering which shows relatively less volatility in the series. This study also confirms the results by Grier and Smallwood (2013), which showed a negative relationship between volatility and exports for emerging markets, although Hall et al. (2010) found such a significant negative relationship for developed markets but an insignificant relationship for a selection of emerging markets.

In line with the expectations, the core model also showed that the level of the exchange rate has a negative and statistically 
significant effect on exports, with a $1 \%$ appreciation of the exchange rate, ceteris paribus, reducing exports by about $0.27 \%$ and $0.30 \%$, respectively, in the models with GARCH and standard deviation. This also makes economic sense as an appreciation of the currency tends to make export goods relatively expensive, which should contain demand thereof. This kind of the relationship is one of the key reasons why some of policy makers argue that stronger exchange rates depress exports and hence call for policies that will keep the level of the exchange rates at competitive levels (Polity.org.za 1996).

The coefficients of G7 industrial production are both positive and statistically significant at the $1 \%$ level in both models. This is in line with economic theory and shows that an increase in economic activity in G7 countries tends to underpin demand for imported goods and services used in the production process. This will imply a rise in exports of trading partners. The core model shows that a $1 \%$ increase in G7 industrial production, ceteris paribus, results in about $1.62 \%$ rise in exports. Production in major countries, therefore, is very crucial for the performance of emerging market exports. This makes perfect economic sense as supply for goods and services is derived, which responds to activity on the demand side. Consumption by G7 countries accounts for a large part of global consumption. According to the International Monetary Fund (2011), demand by G7 countries accounts for more than $50 \%$ of total global demand, hence an increase in activity in those countries underpins demand for factors of production. A large portion of this is supplied by emerging markets.

Terms of trade measure countries' export competitiveness, hence an improvement in terms of trade is expected to have a positive influence on exports. The core models proved this to be true by producing positive coefficients, with a $1 \%$ increase in terms of trade resulting in about $0.76 \%$ and $0.73 \%$ rise in exports, as seen in Table 11. This is significant at the $5 \%$ level.

Overall, the core models produced adjusted $R$-squares of about 0.84 , which indicate that more than $80 \%$ of the variation in the performance of exports is explained by variations of a combination of exchange rate risk, the level of the exchange rate, economic activity in major countries as well as terms of trade. The remaining portion is probably explained by other factors that were excluded in the scope of this research.

\section{Practical implications}

Exchange rate volatility, the key variable in this research, captures risk or uncertainty faced by exporters in international trade. Such uncertainty could have implications on exporters' decision making processes. The outcome of this research suggests that uncertainty in emerging markets business environment, which results from exchange rate instability, discourages exporters from expanding capacity and engaging more in foreign trade.

The dependence of emerging markets on major countries for economic prosperity (which was evident by a statistical significant influence of G7 economic activity on export) makes them vulnerable to exogenous factors, such as the recently experienced 2008-2009 global financial crisis. Emerging economies need to diversify their exports to different regions evenly and invest in infrastructure and skills that will enable them to transform their major exports to usable finished products. This will increase specialisation and help to achieve some of the critical macroeconomic objectives, such as employment creation.

\section{Limitations of the study}

Schwab (2011) established that, in addition to actual quantitative factors, a country's competitiveness from the supply side point of view is another crucial element determining the performance of exports. He identified factors such as infrastructure, institutions, a stable macroeconomic environment, labour market policies, skills and health, amongst others, as important features determining productivity and competitiveness of nations. In order to maximise their export competitiveness, nations have to get those basic elements right. This enables a country to be more competitive through reduced effort in the production process and distribution of the products. Detailed discussions on the impact of those factors were left out of this study and could be scope for future research.

\section{Policy recommendations}

In general, the research confirmed that exchange rate volatility has a statistically negative effect on the performance of exports. Based on these findings, policy makers in exportoriented emerging countries should strive for a policy mix that will ensure stable and relatively weak exchange rates. This is recommended because stable exchange rates will ensure certainty, helping investors to make accurate planning and reduce operational risk, whilst competitive exchange rates will help to ensure that the goods remain competitive relative to foreign markets. A combination of a stable exchange rate environment and a competitive currency will help to attract investment, increase aggregate output and improve countries' economic prosperities.

\section{Conclusion}

This research was intended to provide empirical analysis on the determinants of exports, with specific focus on the effect of exchange rate volatility on the performance of exports. Panel data models were used to determine the nature of the relationship between the two variables in a sample of nine emerging countries. Two measures of exchange rate volatility, namely, standard deviation and GARCH, were used. The core models were unable to find evidence of either positive or no relationship between exchange rate volatility and exports, as was suggested by some theories and studies. The models showed that regardless of the measure of exchange rate volatility used, exchange rate volatility has a negative effect on exports, which was in line with preliminary expectations, economic theory and most other similar studies. The negative 
impact of exchange rate volatility on exports suggests that emerging market exporters are also generally risk averse, with a tendency of reducing their trade activities when the exchange rates became persistently volatile. It thus makes economic sense to expect some reduction in exports growth when the exchange rates become volatile. The exporters could respond by temporarily suspending international trade or reducing their participation in such activities until some sense of certainty returns through reduced exchange rate volatility. In extreme scenarios, high exchange rate volatility could therefore be expected to induce exporters to discontinue international trade activities completely and focus on supplying domestic markets.

\section{Acknowledgements Competing interests}

The authors declare that they have no financial or personal relationship(s) that may have inappropriately influenced them in writing this article.

\section{Authors' contributions}

M.J.K. (University of Johannesburg) conducted research for his minor dissertation for fulfilment of a Master's degree in Economics. He also contributed as author and re-worked the minor dissertation into an article. I.B. (University of Johannesburg) contributed as supervisor and author to the literature review, empirical analysis and submission. M.P. (University of Johannesburg) contributed as co-supervisor and author to the literature review and the empirical analysis.

\section{References}

Aghion, P., Bacchetta, P., Ranciere, R. \& Rogoff, K., 2006, Exchange rate volatility and productivity growth: The role of financial development, Working Paper 12117 , National Bureau of Economic Research, Cambridge, MA

Ahmed, S., 2009, 'Exchange rate volatility and international trade growth: Evidence from Bangladesh', MPRA Paper No 19466, ASA University Review 1, 67-79.

Anderton, R. \& Skudelny, F.,2001, Exchange rate volatility and Euro area imports, European Central Bank Working Paper Series No. 64, European Central Bank, Germany.

Aristotelous, K., 2001, 'Exchange-rate volatility, Exchange-rate regime, and trade volume: Evidence from UK-US export function (1889-1999)', Economics Letters 72(1), 87-94. http://dx.doi.org/10.1016/S0165-1765(01)00414-1

Arize, A., Malindretos, J. \& Kasibhatla, M., 2003, 'Does exchange-rate volatility depress export flows: The case of LDCs', Institute of Applied Economic Research 9(1), 7-20. http://dx.doi.org/10.1007/BF02295297

Asseery, A. \& Peel, D., 1991, 'The effects of exchange rate volatility on exports: Some new estimates', Economics Letters 37(2), 173-177. http://dx.doi. org/10.1016/0165-1765(91)90127-7

Baak, S., Al-Mahmood, M. \& Vixathep, S., 2007, 'Exchange rate volatility and exports from East Asian countries to Japan and the USA', Applied Economics 39(8), 947-959. http://dx.doi.org/10.1080/00036840500474231

Bah, I. \& Amusa, H., 2003, 'Real exchange rate volatility and foreign trade: Evidence from South Africa's exports to the United States', African Finance Journal 5(2), 1-20.

Bailey, M.J., 1988, Trade and investment performance under floating exchange rates: The U.S. experience, IMF Working Paper No. 88/37. http://dx.doi. org/10.1016/0161-8938(87)90010-X

Bailey, M.J., Tavlas, G.S. \& Ulan, M., 1987, 'The impact of exchange rate volatility on export growth: Some theoretical considerations and empirical results', Journa of Policy Modelling 9(1), 225-243.

Bélanger, D., Gutiérrez, S. \& Raynauld, J., 1988, Exchange rate variability and trade flows: Sectoral estimates for the US-Canada case, Cahiers de Recherche IEA-89-01, Institut d'économie appliquée, École des Hautes Études Commerciales, Montreal.

Brada, J.C. \& Méndez, J.A., 1988, 'Exchange rate risk, exchange rate regime and the volume of international trade', Kyklos 41(2), 263-280. http://dx.doi. org/10.1111/j.1467-6435.1988.tb02309.x
Bredin, D., Fountas, S. \& Murphy, E., 2003, 'An empirical analysis of short-run and long-run Irish export functions: Does exchange rate volatility matter?', International Review of Applied Economics 17(2), 193--208. http://dx.doi. International Review of Applied E
org/10.1080/0269217032000064053

Broda, C. \& Romalis, J., 2003, 'Identifying the effect of exchange rate volatility on the composition and volume of trade', unpublished manuscript, FRBNY and Chicago GSB and NBER.

Brooks, C., 2002, Introductory econometrics for finance, Cambridge University Press, Cambridge.

Cakir, M., 2008, 'Trade liberalisation and competitiveness of emerging market economies', Master's dissertation, Economic Development and Policy Issues, Faculty of Economic and Financial Science, University of Johannesburg.

Chit, M.M., 2008, 'Exchange rate volatility and exports: Evidence from the ASEAN-China Free Trade Area', Journal of Chinese Economics and Business Studies 6(3), 261-277. http://dx.doi.org/10.1080/14765280802283543

Chit, M.M., Rizov, M. \& Willenbockel, D., 2010, 'Exchange rate volatility and exports: New empirical evidence from the emerging East Asian economies', The World Economy, 33(2), 239-262. http://dx.doi.org/10.1111/j.1467-9701.2009.01230.x

Cho, G., Sheldon, I. \& McCorriston, S., 2002, 'Exchange rate uncertainty and agricultural trade', American Journal of Agricultural Economics 84(4), 931-942. agricultural trade', American Journal of Agricu
http://dx.doi.org/10.1111/1467-8276.00044

Chowdhury, A.R., 1993, 'Does exchange rate volatility depress trade flows? Evidence from error-correction models', The Review of Economic and Statistics 75(4), 700-706. http://dx.doi.org/10.2307/2110025

Clark, P., 1973, 'Uncertainty, exchange risk, and the level of international trade', Economic Inquiry 11(3), 302-313. http://dx.doi.org/10.1111/j.1465-7295.1973. tb01063.x

Clark, P., Tamirisa, N., Wei, S., Sadikov, A.M. \& Zeng, L., 2004, A new look at exchange rate volatility and trade flows, International Monetary Fund, Occasional Paper Number 235, Washington, DC.

Côté, A., 1994, Exchange rate volatility and trade: a survey, Working Paper Number 94-5, Bank of Canada.

Darrat, A. \& Hakim, S., 2000, 'Exchange rate volatility and trade flows in an emerging market: Some evidence from a GARCH process', Savings and Development 24(3), 287-302.

De Vita, G. \& Abbott, A., 2004, 'The impact of exchange rate volatility on UK exports to EU countries', Scottish Journal of Political Economy 51(1), 62-81. http://dx.doi. org/10.1111/j.0036-9292.2004.05101004.x

De Grauwe, P., 1988, 'Exchange rate variability and the slowdown in growth of international trade', Staff Papers (International Monetary Fund) 35(1), 63-84. http://dx.doi.org/10.2307/3867277

Dogănlar, M., 2002, 'Estimating the impact of exchange rate volatility on exports: Evidence from Asian countries', Applied Economics Letters 9(13), 859-863. http:// dx.doi.org/10.1080/13504850210150906

Égert, B. \& Morales-Zumaquero, A., 2008, 'Exchange rate regimes, foreign exchange volatility and export performance in Central and Eastern Europe: just anothe Blur Project?', Review of Development Economics 12(3), 577-593. http://dx.doi. org/10.1111/j.1467-9361.2008.00473.x

Esquivel, G. \& Larrain, F., 2002, The impact of G-3 exchange rate volatility on developing countries, United Nations Conference on Trade and Development, G-24 Discussion Paper Series, No. 16, United Nations, New York and Geneva.

Franke, G., 1991, 'Exchange rate volatility and international trading strategy', Journal of International Money and Finance 10(2), 292-307. http://dx.doi. org/10.1016/0261-5606(91)90041-H

Gotur, P., 1985, 'Effect of exchange rate volatility on trade: some further evidence', Staff Papers (International Monetary Fund) 32(3), 475-512. http://dx.doi. Staff Papers (Interna
org/10.2307/3866807

Greene, W.H., 2000, Econometric analysis, 4th edn, Prentice Hall, Upper Saddle River.

Grier, K.B. \& Smallwood, A.D., 2013, 'Exchange rate shocks and trade: A multivariate GARCH-M approach', Journal of International Money and Finance 37, 282-305. http://dx.doi.org/10.1016/j.jimonfin.2013.05.010

Polity.org.za, 1996, Growth, employment and redistribution. A macroeconomic strategy 1996, viewed 14 June 2011, from http://www.polity.org.za/polity/ govdocs/policy/growth.htm

Gujarati, D., 2003, Basic econometrics, 4th edn, McGraw Hill, New York.

Hall, S., Hondroyiannis, G., Swamy, P.A.V.B., Tavlas, G., Ulan, M., 2010, 'Exchange-rate volatility and export performance: Do emerging market economies resemble industrial countries or other developing countries?', Economic Modelling 27(6), industrial countries or other developing countries?', Economic
$1514-1521$. http://dx.doi.org/10.1016/j.econmod.2010.01.014

Hausman, J.A., 1978, 'Specification tests in econometrics', Econometrica 46(6), 1251-1271. http://dx.doi.org/10.2307/1913827

Hedeker, D. \& Gibbons, R., 1994, 'A random-effects ordinal regression model for multilevel analysis', Biometrics 50(4), 933-944. http://dx.doi. org $/ 10.2307 / 2533433$

Héricourt, J. \& Poncet, S., 2013, 'Exchange rate volatility, financial constraints and trade: Empirical evidence from Chinese firms', FIW Working Paper No. 112.

Hooper, P. \& Kohlhagen, S., 1978, 'The effect of exchange rate uncertainty on the price and volume of international trade', Journal of International Economics 8(4), 483-511. http://dx.doi.org/10.1016/0022-1996(87)90001-8

Hoover, K.D., 2003, 'Nonstationary time series, cointegration, and the principle of the common cause', British Society for the Philosophy of Science 54, 527-551. http:// dx.doi.org/10.1093/bjps/54.4.527 
Hsiao, C., 2006, 'Panel data analysis - advantages and challenges', IEPR Working Papers 06/49, Institute of Economic Policy Research, University of Southern California.

Hsiao, C., Mountain, D.C. \& Ho Illman, K., 1995, 'A Bayesian integration of end-use metering and conditional-demand analysis', Journal of Business \& Economic Statistics 13(3), 315-326. http://dx.doi.org/10.2307/1392191

Im, K.S., Pesaran, M.H. \& Shin, Y., 2003, 'Testing for unit roots in heterogeneous panel', Journal of Econometrics 115(1), 53-74. http://dx.doi.org/10.1016/ S0304-4076(03)00092-7

International Monetary Fund,1984, Exchange rate volatility and world trade, IMF Occasional Papers (No. 28), International Monetary Fund, Washington, DC.

International Monetary Fund, 2011, World economic outlook database, viewed 11 April 2011, from http://www.imf.org/external/pubs/ft/weo/2011/01/ weodata/index.aspx

Judge, G.G., Griffiths, W.E., Hill, R.C., Lütkepohl, H. \& Lee, T.C.,1985, The theory and practice of econometrics, 2nd edn, John Wiley \& Sons, New York.

Kandilov, I.T., 2008, 'The effects of exchange rate volatility on agricultural trade', American Journal of Agricultural Economics 90(4), 1028-1043. http://dx.doi. org/10.1111/j.1467-8276.2008.01167.x

Klaassen, F., 2004, 'Why it is so difficult to find an effect of exchange rate risk on trade?', Journal of International Money and Finance 23(5), 817-839. http://dx.doi. org/10.1016/j.jimonfin.2004.03.009

Koray, F. \& Lastrapes, W., 1989, 'Real exchange rate volatility and U.S. bilateral trade: A VAR approach', The Review of Economics and Statistics 71(4), 708-712. $\mathrm{http}: / / \mathrm{dx}$.doi.org/10.2307/1928117

Kroner, K. \& Lastrapes, W., 1993, 'The impact of exchange rate volatility on international trade: Reduced form estimates using the GARCH-in-mean model', Journal of International Money and Finance 12(3), 298-318. http://dx.doi. org/10.1016/0261-5606(93)90016-5

Levin, A., Lin, C.F. \& Chu, J., 2002, 'Unit root tests in panel data: asymptotic and finite sample properties', Journal of Econometrics 108(1), 1-24. http://dx.doi. org/10.1016/S0304-4076(01)00098-7

Longford, N.T., 1993, Random coefficient models, Clarendon Press, Oxford.

MaCurdy, T.E., 1981, 'An empirical model of labor supply in a life cycle setting', Journal of Political Economy 89(6), 1059-1085. http://dx.doi.org/10.1086/261023

Marston, R.C.,1987, Exchange rate policy reconsidered, NBER Working Paper Series, No. 2310, National Bureau of Economic Research, Cambridge, MA.

Obstfeld, M. \& Rogoff, K., 1995, 'The mirage of fixed exchange rates', Journal of Economic Perspectives 9(4), 73-96. http://dx.doi.org/10.1257/jep.9.4.73
Onafowora, O.A. \& Owoye, O., 2008, 'Exchange rate volatility and export growth in Nigeria', Applied Economics 40(12) 1547-1556. http://dx.doi. growth in Nigeria', Applied Econo
org/10.1080/00036840600827676

Pedroni, P., 1999, 'Critical values for cointegration tests in heterogenous panels with multiple regressors', Oxford Bulletin of Economics and Statistics 61(S1), 653-670. http://dx.doi.org/10.1111/1468-0084.61.s1.14

Perman, R. \& Stern, D.I., 2003, 'Evidence from panel unit root and cointegration tests that the Environmental Kuznets Curve does not exist', The Australian Journal of Agricultural and Resource Economics 47(3), 325-347. http://dx.doi. org/10.1111/1467-8489.00216

Pesaran, M.H., Shin, Y. \& Smith, R.J., 2001, 'Bounds testing approaches to the analysis of level relationships', Journal of Applied Econometrics 16(3), 289-326. http:// dx.doi.org/10.1002/jae.616

Robinson, P.M., 1987, 'Asymptotically efficient estimation in the presence of heteroskedasticity of unknown form', Econometrica 55(4), 875-891. http://dx.doi. org/10.2307/1911033

Schwab, K., 2011, The global competitiveness report 2011-2012, World Economic Forum, Geneva, Switzerland.

Sercu, P. \& Vanhulle, C., 1992, 'Exchange rate volatility, international trade, and the value of exporting firms', Journal of Banking \& Finance 16(1), 155-182. the value of exporting firms', Journal of Banking
http://dx.doi.org/10.1016/0378-4266(92)90083-C

Solakoglu, M.N., Solakoglu, E.G. \& Demirağ, T., 2008, 'Exchange rate volatility and exports: A firm-level analysis', Applied Economics 40(7), 921-929. http://dx.doi. org/10.1080/00036840600749888

Takaendesa, P., Tsheole, T. \& Aziakpono, M., 2006, 'Real exchange rate volatility and its effect on trade flows: New evidence from South Africa', Journal for Studies in Economics and Econometrics 30(3), 79-97.

Tenreyro, S., 2007, 'On the trade impact of nominal exchange rate volatility', Journal of Development Economics 82, 485-508. http://dx.doi.org/10.1016/j. jdeveco.2006.03.007

Thursby, J.G. \& Thursby, M.C., 1987, 'Bilateral trade flows, the Linder hypothesis, and exchange risk', The Review of Economics and Statistics 69(3), 488-495. http://dx.doi.org/10.2307/1925537

Vergil, H., 2002, 'Exchange rate volatility in Turkey and its effect on trade flows', Journal of Economic and Social Research 4(1), 83-99.

Verheyen, F., 2012, 'Bilateral exports from euro zone countries to the US - Does exchange rate variability play a role?', International Review of Economics \& Finance 24, 97-108. http://dx.doi.org/10.1016/j.iref.2012.01.007

Wooldridge, J.M., 2002, Econometric analysis of cross section and panel data, MIT Press, Cambridge, MA. 


\section{Appendix 1}

TABLE 1-A1: Summary of selected studies on the impact of exchange rate volatility.

\begin{tabular}{|c|c|c|c|c|c|c|}
\hline Researcher & Name of the study & Data period & Variables & $\begin{array}{l}\text { Exchange rate } \\
\text { volatility measure }\end{array}$ & $\begin{array}{l}\text { Estimation } \\
\text { method }\end{array}$ & Results \\
\hline Ahmed (2009) & $\begin{array}{l}\text { 'Exchange rate volatility and } \\
\text { international trade growth: } \\
\text { evidence from Bangladesh' }\end{array}$ & $\begin{array}{l}\text { Monthly: May } \\
2003 \text { to Dec } \\
2008\end{array}$ & $\begin{array}{l}\text { Real exports, real bilateral } \\
\text { exchange rate, Industrial } \\
\text { production index of importing } \\
\text { countries, relative price level, } \\
\text { exchange rate volatility }\end{array}$ & Standard deviation & $\begin{array}{l}\text { Error-correction } \\
\text { models }\end{array}$ & $\begin{array}{l}\text { Exchange rate volatility } \\
\text { does not have a significant } \\
\text { impact on exports of } \\
\text { Bangladesh for both short- } \\
\text { run and long-run. }\end{array}$ \\
\hline $\begin{array}{l}\text { Arize, Malindretos \& } \\
\text { Kasibhatla (2003) }\end{array}$ & $\begin{array}{l}\text { 'Does exchange-rate } \\
\text { volatility depress export } \\
\text { flows: the case of LDCs' }\end{array}$ & $\begin{array}{l}\text { Quarterly: } \\
1973 \text { to } 1998\end{array}$ & $\begin{array}{l}\text { Export goods, world demand } \\
\text { conditions (world GDP), } \\
\text { relative prices, terms of trade }\end{array}$ & $\begin{array}{l}\text { 7-period moving- } \\
\text { sample standard } \\
\text { deviation }\end{array}$ & $\begin{array}{l}\text { Johansen } \\
\text { method of } \\
\text { cointegration }\end{array}$ & Negative affect of exports. \\
\hline Bailey (1988) & $\begin{array}{l}\text { 'Trade and investment } \\
\text { performance under floating } \\
\text { exchange rates: the U.S. } \\
\text { experience' }\end{array}$ & $\begin{array}{l}\text { Quarterly: } \\
1975 \text { to } 1988\end{array}$ & $\begin{array}{l}\text { US export volume, foreign } \\
\text { income, real exchange rate, } \\
\text { exchange rate volatility }\end{array}$ & $\begin{array}{l}\text { Standard deviation and } \\
\text { percentage change in } \\
\text { real effective exchange } \\
\text { rate }\end{array}$ & $\begin{array}{l}\text { Ordinary least } \\
\text { squares }\end{array}$ & $\begin{array}{l}\text { Insignificant negative } \\
\text { relationship. }\end{array}$ \\
\hline $\begin{array}{l}\text { Bélanger, Gutiérrez \& } \\
\text { Raynauld (1988) }\end{array}$ & $\begin{array}{l}\text { 'Exchange rate variability } \\
\text { and trade flows: sectoral } \\
\text { estimates for the US- } \\
\text { Canada case' }\end{array}$ & $\begin{array}{l}\text { Quarterly: } \\
1976 \text { to } 1987\end{array}$ & $\begin{array}{l}\text { US exports to Canada, } \\
\text { nominal exchange rate }\end{array}$ & $\begin{array}{l}\text { Squared forecast error } \\
\text { three month forward } \\
\text { spread }\end{array}$ & $\begin{array}{l}\text { Cross-section } \\
\text { method }\end{array}$ & $\begin{array}{l}\text { Significant negative } \\
\text { relationship in two sectors. }\end{array}$ \\
\hline Brada \& Méndez (1988) & $\begin{array}{l}\text { 'Exchange rate risk, } \\
\text { exchange rate regime and } \\
\text { the volume of international } \\
\text { trade' }\end{array}$ & $\begin{array}{l}\text { Annual: } \\
1973 \text { to } 1977\end{array}$ & $\begin{array}{l}\text { Exports amongst } 30 \text { countries } \\
\text { and dummy for exchange } \\
\text { regime }\end{array}$ & $\begin{array}{l}\text { Dummy for real } \\
\text { exchange }\end{array}$ & $\begin{array}{l}\text { Cross-section } \\
\text { method }\end{array}$ & $\begin{array}{l}\text { Significantly positive during } \\
\text { the period of floating } \\
\text { exchange rate regime. }\end{array}$ \\
\hline $\begin{array}{l}\text { Bredin, Fountas \& } \\
\text { Murphy (2003) }\end{array}$ & $\begin{array}{l}\text { 'An empirical analysis of } \\
\text { short-run and long-run } \\
\text { Irish export functions: does } \\
\text { exchange rate volatility } \\
\text { matter?' }\end{array}$ & $\begin{array}{l}\text { Quarterly: } \\
1978 \text { to } 1998\end{array}$ & $\begin{array}{l}\text { Export volume, foreign } \\
\text { income, relative prices and } \\
\text { exchange rate volatility }\end{array}$ & Standard deviation & $\begin{array}{l}\text { Error-correction } \\
\text { models }\end{array}$ & $\begin{array}{l}\text { Exchange rate volatility has } \\
\text { no effect in the short-run } \\
\text { but a significant positive } \\
\text { effect in the long-run. }\end{array}$ \\
\hline Chowdhury (1993) & $\begin{array}{l}\text { 'Does exchange rate } \\
\text { volatility depress trade } \\
\text { flows? Evidence from error- } \\
\text { correction models' }\end{array}$ & $\begin{array}{l}\text { Quarterly: } \\
1973 \text { to } 1990\end{array}$ & $\begin{array}{l}\text { Real export volume, real } \\
\text { foreign economic activity, } \\
\text { relative prices, terms of trade }\end{array}$ & $\begin{array}{l}\text { Real exchange rate } \\
\text { standard deviation }\end{array}$ & $\begin{array}{l}\text { Error-correction } \\
\text { models }\end{array}$ & $\begin{array}{l}\text { Exchange rate volatility } \\
\text { has a negative effect on } \\
\text { exports. }\end{array}$ \\
\hline Dogănlar (2002) & $\begin{array}{l}\text { 'Estimating the impact of } \\
\text { exchange rate volatility on } \\
\text { exports: evidence from } \\
\text { Asian countries' }\end{array}$ & $\begin{array}{l}\text { Quarterly: } \\
1980 \text { to } 2002\end{array}$ & $\begin{array}{l}\text { Real exports, industrialised } \\
\text { countries industrial } \\
\text { production, terms of trade, } \\
\text { exchange rate uncertainty }\end{array}$ & $\begin{array}{l}\text { Moving standard } \\
\text { deviation of the growth } \\
\text { of the real exchange } \\
\text { rate }\end{array}$ & $\begin{array}{l}\text { Error-correction } \\
\text { models }\end{array}$ & $\begin{array}{l}\text { Exchange rate volatility } \\
\text { reduced real exports. }\end{array}$ \\
\hline $\begin{array}{l}\text { Esquivel \& Larraín } \\
\text { (2002) }\end{array}$ & $\begin{array}{l}\text { 'The impact of G-3 } \\
\text { exchange rate volatility on } \\
\text { developing countries' }\end{array}$ & $\begin{array}{l}\text { Annually: } \\
1973 \text { and } 1998\end{array}$ & $\begin{array}{l}\text { Real exports, real world GDP, } \\
\text { real effective exchange rate, } \\
\text { exchange rate volatility }\end{array}$ & $\begin{array}{l}\text { Standard deviation of } \\
\text { the growth rates of real } \\
\text { exchange rates }\end{array}$ & $\begin{array}{l}\text { Vector } \\
\text { autoregressive } \\
\text { model }\end{array}$ & $\begin{array}{l}\text { Exchange rate volatility has } \\
\text { negative impact on trade } \\
\text { flows. }\end{array}$ \\
\hline Kandilov (2008) & $\begin{array}{l}\text { 'The effects of exchange } \\
\text { rate volatility on agricultural } \\
\text { trade' }\end{array}$ & $\begin{array}{l}\text { Annually: } \\
1975 \text { to } 1997\end{array}$ & $\begin{array}{l}\text { Real exports, GDP, population } \\
\text { growth, transport costs, } \\
\text { distance between nations, } \\
\text { exchange rate volatility }\end{array}$ & GARCH specification & $\begin{array}{l}\text { Gravity equation } \\
\text { model }\end{array}$ & $\begin{array}{l}\text { Exchange rate volatility has } \\
\text { a large negative impact on } \\
\text { agricultural trade between } \\
\text { members of the } \mathrm{G} 10 \\
\text { countries. }\end{array}$ \\
\hline $\begin{array}{l}\text { Koray \& Lastrapes } \\
\text { (1989) }\end{array}$ & $\begin{array}{l}\text { 'Real exchange rate } \\
\text { volatility and U.S. bilateral } \\
\text { trade: a VAR approach' }\end{array}$ & $\begin{array}{l}\text { Monthly: } \\
1961 \text { to } 1985\end{array}$ & $\begin{array}{l}\text { Real exports, relative prices, } \\
\text { imports of trading partners, } \\
\text { exchange rate volatility }\end{array}$ & $\begin{array}{l}\text { 12-month moving } \\
\text { standard deviation of } \\
\text { real exchange rate }\end{array}$ & $\begin{array}{l}\text { Vector } \\
\text { autoregressive } \\
\text { model }\end{array}$ & Negative, but weak. \\
\hline $\begin{array}{l}\text { Kroner \& Lastrapes } \\
\text { (1993) }\end{array}$ & $\begin{array}{l}\text { 'The impact of exchange } \\
\text { rate volatility on } \\
\text { international trade: reduced } \\
\text { form estimates using the } \\
\text { GARCH-in-mean model' }\end{array}$ & $\begin{array}{l}\text { Monthly: } \\
1973 \text { to } 1990\end{array}$ & $\begin{array}{l}\text { Exchange rate variability, } \\
\text { international trade, reduced } \\
\text { form estimates }\end{array}$ & GARCH model & $\begin{array}{l}\text { Ordinary least } \\
\text { squares }\end{array}$ & Mixed results. \\
\hline $\begin{array}{l}\text { Héricourt \& Poncet } \\
\text { (2013) }\end{array}$ & $\begin{array}{l}\text { 'Exchange rate volatility, } \\
\text { financial constraints and } \\
\text { trade: empirical evidence } \\
\text { from Chinese firms' }\end{array}$ & $\begin{array}{l}\text { Monthly: } \\
2000 \text { to } 2006\end{array}$ & $\begin{array}{l}\text { Export performance, } \\
\text { financial vulnerability, } \\
\text { financial development, } \\
\text { export performance and real } \\
\text { exchange rate volatility }\end{array}$ & $\begin{array}{l}\text { Standard deviation of } \\
\text { monthly log differences }\end{array}$ & Panel analysis & Negative effect. \\
\hline $\begin{array}{l}\text { Chit, Rizov \& } \\
\text { Willenbockel (2010) }\end{array}$ & $\begin{array}{l}\text { 'Exchange rate volatility } \\
\text { and exports: new empirical } \\
\text { evidence from the emerging } \\
\text { East Asian economies' }\end{array}$ & $\begin{array}{l}\text { Quarterly: } \\
1982 \text { to } 2006\end{array}$ & $\begin{array}{l}\text { Real exports, relative prices, } \\
\text { home income, foreign } \\
\text { income, volatility }\end{array}$ & $\begin{array}{l}\text { GARCH and standard } \\
\text { deviation }\end{array}$ & Panel analysis & Negative relationship. \\
\hline $\begin{array}{l}\text { Grier \& Smallwood } \\
\text { (2013) }\end{array}$ & $\begin{array}{l}\text { 'Exchange rate shocks } \\
\text { and trade: a multivariate } \\
\text { GARCH-M approach' }\end{array}$ & $\begin{array}{l}\text { Monthly: } \\
1973 \text { to } 2007\end{array}$ & $\begin{array}{l}\text { Multilateral exports, foreign } \\
\text { income, volatility }\end{array}$ & GARCH & $\begin{array}{l}\text { Multivariate } \\
\text { GARCH }\end{array}$ & Negative relationship. \\
\hline Verheyen (2012) & $\begin{array}{l}\text { 'Bilateral exports from } \\
\text { euro zone countries to the } \\
\text { US - Does exchange rate } \\
\text { variability play a role?' }\end{array}$ & $\begin{array}{l}\text { Monthly: } \\
1992 \text { to } 2010\end{array}$ & $\begin{array}{l}\text { Bilateral exports, volatility } \\
\text { and foreign income }\end{array}$ & $\begin{array}{l}\text { Standard deviation and } \\
\text { GARCH }\end{array}$ & $\begin{array}{l}\text { Bounds testing } \\
\text { approach }\end{array}$ & Negative relationship. \\
\hline Hall et al. (2010) & $\begin{array}{l}\text { 'Exchange-rate volatility } \\
\text { and export performance: } \\
\text { Do emerging market } \\
\text { economies resemble } \\
\text { industrial countries or other } \\
\text { developing countries?' }\end{array}$ & $\begin{array}{l}\text { Quarterly: } \\
1980 \text { to current }\end{array}$ & Exports, volatility, income & $\begin{array}{l}\text { Standard deviation and } \\
\text { GARCH }\end{array}$ & $\begin{array}{l}\text { Panel } \\
\text { analysis with } \\
\text { time-varying } \\
\text { parameter and } \\
\text { generalised } \\
\text { method of } \\
\text { moments }\end{array}$ & $\begin{array}{l}\text { Negative relationship in } \\
\text { developed countries but } \\
\text { inconclusive for emerging } \\
\text { markets (open capital } \\
\text { markets reduce effect). }\end{array}$ \\
\hline
\end{tabular}

Source: Various studies

GDP, Gross Domestic Profit; GARCH, Generalised Autoregressive Conditional Heteroscedasticity. 